\title{
Genetic Diversity of Appemidi Mango (Mangifera indica L.) in Belagavi district of Karnataka on Tree and Leaf Characters
}

\author{
C.J. Nithin Kumar ${ }^{1 *}$, D.R. Patil' ${ }^{2}$, Nagesh Naik ${ }^{3}$, H.R. Manukumar ${ }^{4}$, \\ Y.K. Kotikal ${ }^{5}$, B. Tambat ${ }^{6}$ and D.S. Ambika ${ }^{7}$ \\ ${ }^{1}$ Dept. of Fruit Science, COH, UHS, Bagalkot, Karnataka \\ ${ }^{2}$ Dept. of Fruit Science, ADRE, UHS, Bagalkot \\ ${ }^{3}$ Dept. of Fruit Science, Dean, KRCCH, UHS, Arabhavi \\ ${ }^{4}$ Dept. of Fruit Science COH, UHS, Sirsi \\ ${ }^{5}$ Dept. Entomology and Director of Extension, UHS, Bagalkot \\ ${ }^{6}$ Dept. of Crop Physiology, COA, UAS, Hassan \\ ${ }^{7}$ Plant Pathology, KVK, Kolar, India \\ *Corresponding author
}

\section{A B S T R A C T}

Keywords

Appemidi mango, pickle, Belagavi, conservation and genotypes

Article Info

Accepted:

05 January 2019

Available Online:

10 February 2020
Mango is one of the most important fruit crop of India due to its massive diversity in its flavour, aroma, taste and fruit form. Western Ghats region of Karnataka is having huge diversity of aromatic pickle mango called appemidi. The appemidi mango is used for pickling purpose because of its unique character like flavor, taste and good keeping quality. Number of appemidi trees is decreasing due unhealthy harvesting, de-forestation and hydroelectric projects. Exploratory survey was carried out in Western Ghats region of Belagavito conserve the genotypes. The survey results in the collection of 7 genotypes from Belagavi district and studied their morphological traits and conserved in field gene banks. Further theses genotypes can be utilized in crop improvement programme.

\section{Introduction}

India is blessed with the rich diversity of mango. The genus Mangifera belongs to the family Anacardiaceae which is the important fruit crop of the tropics (Mukherjee, 1951).The cultivated mango has originated in India as reported that by Hooker (1876); De- candolle (1904); Mukherjee (1951, 1953, 1972). Vavilov (1926) reported Indo-Burma region as the center of origin of mango, based on the observed level of genetic diversity. Origin of genus Mangifera probably in the South-East Asia, but the origin of cultivated mango in the Assam- Burma region (Mukherjee, 1951). The Western Ghats is 
largely unexplored for the whole fruited pickle genotypes locally called 'Appemidi'.Karnataka state has unique position with respect to the diversity of pickling mango varieties (Vasudeva et al., 2015).

'Appemidi' is the king of all tender mangoes as far as its use in pickle industry is concerned. It has been recently provided with the geographical indication (GI) registration by the Government of India.The Appemidi is native to the forests of Western Ghats, where there are natural vegetation of centuries-old mango trees.

The trees are also found in places like Chittoor and Khanapurin Belagavi. Appemidi, as it is known in Kannada, literally means the raw, aromatic tender mango.

It is a special type of pickling mango types and it is collected extensively from the forest and processed as a pickle.Pickling mango fruits are extremely sour and their unique fragrant aroma made them highly valuable for pickle industry.

\section{Materials and Methods}

Based on the diversity richness, a wellplanned survey on collection of Appemidi mangoes was carried out in area like Londa, Gunji, Khanapur, Malaprabariver, Hemmadaga, Watre and Kanakumbiof Belagavi District, Karnataka, by conducting the survey. Seven genotypes were collected from different regions and each genotypes names were given depending upon their place of collection. The tree and leaf were characterized.

Morphological observations were taken as per the IPGRI descriptor for mango. (Anon., 2006). A. Tree characters viz., 1.Tree type (a.
Seedling b. Grafted), 2. Tree age (a. Old (>40 years), b. Medium (20-40 years), c. Young (< 20 years)), 3. Height of mature tree (m) (a.Short $(\leq 6.0)$, b. Medium $(6.1-9.0)$, c. Tall $(9.1-12.0)$, d. Very tall $(>12.0)), 4$. Girth of the tree $(\mathrm{cm})$ (observation was taken at $50 \mathrm{~cm}$ above ground level in the mature tree), 5. Crown shape (a. Oblong, b. Broadly pyramidal, c. Semi-circular and d. Spherical), 6. Tree growth habit (a. Erect, b. Spreading and c. Drooping) 7. Foliage density (a. Sparseb. Intermediate and c. Dense).

B. Leaf characters viz., 1. Leaf blade shape (a. Elliptic, b. Oblong, c. Ovate d. Obovate, e. Lanceolate and f. Oblanceolate) 2. Leaf blade length $(\mathrm{cm})$ (Average of 5 mature leaves measured from the base to tip of the leaf blade), 3. Leaf blade width $(\mathrm{cm})$ (Average of 5 mature leaves measured at the widest point), 4.Petiole length $(\mathrm{cm})$ (Average length of 5 mature leaves measured from the stem to the base of leaf blade) 5. Leaf texture (a. Coriaceous, b. Chartaceous and c. Membranous), 6. Leaf apex shape (a. Obtuse, b. Acute and Acuminate), 7. Leaf base shape (a. Acute, b. Obtuse and c. Round) 7. Leaf margin (a. Entire and b. Wavy) 8. Colour of young leaf (Recorded on 5-10 days old leaves; a. Light green, b. Light green with brownish tinge, c. Light brick red, and d. Reddish brown, and e. Deep coppery tan), 9. Colour of fully developed leaf (a. Pale green, b. Green and c. Dark green) 10. Leaf fragrance (a. Absent, b. Mild and c. Strong).

\section{Results and Discussion}

Morphological characterization is the simplest and formal standardized method for evaluating crop genetic diversity which could be the first step for analysis based on the visual attributes (Hoogendijk and Williams, 2001). 
Table.1 Tree characters of appemidi mango from coastal and malnad regions of Karnataka

\begin{tabular}{|c|l|l|l|c|c|c|c|c|}
\hline $\begin{array}{c}\text { Sl. } \\
\text { No. }\end{array}$ & \multicolumn{1}{|c|}{ Genotypes } & Tree type & Tree age & $\begin{array}{c}\text { Height of } \\
\text { mature } \\
\text { tree }(\mathbf{m})\end{array}$ & $\begin{array}{c}\text { Girth of } \\
\text { the tree } \\
\text { (cm) }\end{array}$ & $\begin{array}{c}\text { Crown } \\
\text { shape }\end{array}$ & $\begin{array}{c}\text { Tree } \\
\text { growth } \\
\text { habit }\end{array}$ & $\begin{array}{c}\text { Foliage } \\
\text { density }\end{array}$ \\
\hline $\mathbf{1}$ & Londaappe & Seedling & $>40$ years & 12 & 299 & Oblong & Erect & Intermediate \\
\hline $\mathbf{2}$ & Gunjiappe & Seedling & $>40$ years & 10 & 128 & Oblong & Erect & Dense \\
\hline $\mathbf{3}$ & Khanapurappe & Seedling & $>40$ years & 15 & 165 & Oblong & Erect & Intermediate \\
\hline $\mathbf{4}$ & Maladeviappe & Seedling & $>40$ years & 12 & 295 & Spherical & Erect & Intermediate \\
\hline $\mathbf{5}$ & Hemmadagaappe & Seedling & $>40$ years & 12 & 297 & Oblong & Erect & Intermediate \\
\hline $\mathbf{6}$ & Dokaambeappe & Seedling & $>40$ years & 19 & 192 & Oblong & Erect & Intermediate \\
\hline $\mathbf{7}$ & Kanakumbiappe & Seedling & $>40$ years & 16 & 173 & Oblong & Erect & Intermediate \\
\hline
\end{tabular}

Table.2a Leaf characters of appemidi mango from coastal and malnad regions of Karnataka

\begin{tabular}{|l|l|l|l|c|c|c|c|}
\hline $\begin{array}{c}\text { SI. } \\
\text { No. }\end{array}$ & \multicolumn{1}{|c|}{ Genotypes } & $\begin{array}{c}\text { Leaf } \\
\text { blade } \\
\text { shape }\end{array}$ & $\begin{array}{c}\text { Leaf blade } \\
\text { length }(\mathbf{c m})\end{array}$ & $\begin{array}{c}\text { Leaf blade } \\
\text { width }(\mathbf{c m})\end{array}$ & $\begin{array}{c}\text { Petiole } \\
\text { length } \\
\text { (cm) }\end{array}$ & $\begin{array}{c}\text { Leaf } \\
\text { texture }\end{array}$ & $\begin{array}{c}\text { Leaf } \\
\text { apex } \\
\text { shape }\end{array}$ \\
\hline $\mathbf{1}$ & Londaappe & Elliptic & 17.5 & 3.5 & 1.8 & Coriaceous & Acute \\
\hline $\mathbf{2}$ & Gunjiappe & Elliptic & 19.0 & 4.0 & 2.2 & Coriaceous & Obtuse \\
\hline $\mathbf{3}$ & Khanapurappe & Elliptic & 12.8 & 4.3 & 1.5 & Coriaceous & Acute \\
\hline $\mathbf{4}$ & Maladeviappe & Elliptic & 15.2 & 3.1 & 2.0 & Coriaceous & Acute \\
\hline $\mathbf{5}$ & Hemmadagaappe & Elliptic & 13.5 & 3.4 & 1.5 & Coriaceous & Obtuse \\
\hline $\mathbf{6}$ & Dokaambeappe & Elliptic & 10.8 & 4.3 & 1.8 & Coriaceous & Acute \\
\hline $\mathbf{7}$ & Kanakumbiappe & Elliptic & 13.3 & 3.8 & 2.3 & Coriaceous & Acute \\
\hline
\end{tabular}

Tree characters

Tree characters viz. tree type, tree age, height of mature tree, girth of the tree, crown shape, tree growth habit and foliage density (Table 1) were studied in 7 surveyed genotypes. The tree growth recorded erect, spreading and drooping in habit which is in conformity with the observations of Simi (2006) and Mussane et al. (2010) who also found that 50per cent of the trees in mango varieties had spreading and 43.3 per cent had erect growth habit Foliage density in 7 genotypes was observed intermediate and dense and results are similar to the findings of Majumdaret al. (2011).
Majumdaret al. (2011) also revealed that, in 60 accessions of mango, the foliage density varied from sparse to dense. With respect to crown shape, maximum genotypes was observed oblong in shape. These results are similar to the results of Mussane et al (2010) who found that majority of mango varieties showed oblong crown shape.

\section{Leaf characters}

The leaf characters viz., leaf blade shape, leaf blade length, leaf blade width, petiole length, leaf texture, leaf apex shape, leaf base shape, 
leaf margin, colour of young leaf, colour of fully developed leaf and leaf fragrance were recorded (Table $2 \mathrm{a} \& \mathrm{~b}$ ).

Leaf blade shape among 7genotypes recorded elliptic in shape. Mussane et al. (2010) and Rajwana et al. (2011) also found leaf shape varies from elliptic to ovate and reported that mango leaf shape is a good trait for varietal differentiation. In these genotypes, leaf blade length, width and petiole length varied from $10.8 \mathrm{~cm}$ to $19.0 \mathrm{~cm}, 3.1 \mathrm{~cm}$ to $4.3 \mathrm{~cm}$ and 1.5 to $2.3 \mathrm{~cm}$, respectively.

Variation in leaf length, width and petiole length in mango was also reported by Radha and Manjula (2000) and Manohar et al., (2015). Leaf apex shape was found from obtuse to acuminate. Whereas leaf base shape was recorded acute.

Similar variation in leaf apex and leaf base shape was observed by Ramessur and Sanmukhiya(2011). According to Lopez et al., (2010) and Rajwana et al., (2011), variations in leaf apex shape and base shape have been found to be related with genotype and eco-geographical locations of mango germplasm.

All the genotypes was recorded light green colour in young leaves and with dark green in mature or fully developed leaves with mild fragrance and some of the genotypes leaves were high in aroma.

Table. 2b Leaf characters of appemidi mango from coastal and malnad regions of Karnataka

\begin{tabular}{|c|l|c|c|c|c|c|}
\hline $\begin{array}{c}\text { Sl. } \\
\text { No. }\end{array}$ & \multicolumn{1}{|c|}{ Genotypes } & $\begin{array}{c}\text { Leaf base } \\
\text { shape }\end{array}$ & $\begin{array}{c}\text { Leaf } \\
\text { margin }\end{array}$ & $\begin{array}{c}\text { Colour of } \\
\text { the young } \\
\text { leaf }\end{array}$ & $\begin{array}{c}\text { Colour of } \\
\text { fully } \\
\text { developed leaf }\end{array}$ & $\begin{array}{c}\text { Leaf } \\
\text { fragrance }\end{array}$ \\
\hline $\mathbf{1}$ & Londaappe & Acute & Entire & Light green & Dark green & Mild \\
\hline $\mathbf{2}$ & Gunjiappe & Acute & Wavy & Light green & Dark green & Mild \\
\hline $\mathbf{3}$ & Khanapurappe & Acute & Wavy & Light green & Dark green & Mild \\
\hline $\mathbf{4}$ & Maladeviappe & Acute & Wavy & Light green & Dark green & Mild \\
\hline $\mathbf{5}$ & Hemmadagaappe & Acute & Entire & Light green & Dark green & Mild \\
\hline $\mathbf{6}$ & Dokaambeappe & Acute & Wavy & Light green & Dark green & Mild \\
\hline $\mathbf{7}$ & Kanakumbiappe & Acute & Entire & Light green & Dark green & Mild \\
\hline
\end{tabular}

Simi (2006) also reported that light green with brown tinge colour of young flush predominantly appeared in traditional mango types of southern Kerala. Razaet al., (2017) also found a variation in leaf fragrance and found that most of the germplasm have mild fragrance whereas few accessions produced strong fragrance.

\section{References}

Anonymous, 2006, Descriptors for Mango (Mangifera indica L.). International Plant Genetic Resources Institute
IPGRI, Rome, Italy.

De-candolle, A.D.E., 1904, Origin of cultivated plants. Kegan Paul, London.

Hoogendijk, M. and Williams, D., 2001, Characterizing the genetic diversity of home garden crops: Some examples from Americas. $2^{\text {nd }}$ International Home Gardens Workshop, 17-19 July, 2001, Witzenhausen, Federal Republic of Germany, pp: 34-40.

Hooker, J.D., 1876, The Flora of British India, State For India in Council: L. Reeve, London.

Lopez, G.D., Figueroa, S.M., Anaya, A.M. and Perez, M.N., 2010, Morphological 
characterization of native mangoes from Chiapas, Mexico. Subtropical Plant Sci.,62: 18-26.

Majumder, D.A.N. Hassan, L., Rahim, M.A. and Kabir, M.A., 2011 a, Studies on physio-morphology, floral biology and fruit characteristics of mango. $J$. Bangladesh Agril. Univ.,9(2): 187-199.

Manohar, S., Vasudeva, R., Sthapit, B., Parthasarathy, V.A. and Reddy, B.M.C. and Rao, V.R., 2015,Morphological characterization of a few farmers'identified unique aromatic pickle mango (Appemidi) varieties of the central Western Ghats.Indian J. Pl. Gen. Resour.,28(1): 117-122.

Mukherjee, S. K., 1951, Origin of mango, Indian J. Gen. and Plant Bree., 11: 4956.

Mukherjee, S. K., 1953, The mango its botany, cultivation, uses and future improvement, especially as observed in India, Econ. Bot., 7:130-162.

Mukherjee, S. K., 1972, Origin of Mango (Mangifera indica), Econ. Bot., 26: 260264.

Mussane, C.R.B., Biljon, A.V. and Herselman, L., 2010, Morphological and genetic characterization of mango varieties in Mozambique. $2^{\text {nd }}$ RUFORUM Biennial Meeting, Uganda, pp: 991-995.

Radha, T. and Manjula, C., 2000, Characteristics of some polyembryonic mango types grown under Kerala conditions. Acta Hort., 509: 135-142.
Rajwana, I.A., Khan, I.A., Malik, A.U., Saleem, B.A., Khan, A.S., Ziaf, K., Anwar, R. and Amin. M., 2011, Morphological and bio-chemical markers for varietal characterization and quality assessment of potential indigenous mango (Mangifera indica L.) germplasm. Int. J. Agri. Biot., 13: 151-158.

Ramessur, A.D. and Sanmukhiya, R.V.M., 2011, RAPD marker-assisted identification of genetic diversity among mango (Mangifera indica) varieties in Mauritius. Int. J. Agri. Biol., 13: 167-173.

Raza, S.A, Khan, A.S., Khan, I.A., Rajwana, I.A., Ali, S., Khan, A.A. and Rehman, A., 2017, Morphological and physicochemical diversity in some indigenous mango (Mangifera indica L.) germplasm of Pakistan. Pakistan J. Agri. Sci.,54(2): 287-297.

Simi, S., 2006, Characterization of traditional mango (Mangifera indica L.) varieties of southern Kerala. Ph. D Thesis. Kerala Agricultural University, pp:171.

Vasudeva, R., Reddy, B.M.C., Sthapit, B.and Rao, V.R., 2015, An informal network of grafting experts to help the communities to conserve and utilize wild-aromatic pickle-mango (Mangifera indica) diversity in the Central Western Ghats, India. ActaHortic., 11(1): 63-67.

Vavilov, N.I., 1926, Centres of Origin of Cultivated Plants, Bulle. Appl. Bot. Genet. Plant Breed., 16: 1-248.

\section{How to cite this article:}

Nithin Kumar C.J., D.R. Patil, Nagesh Naik, H.R. Manukumar, Y.K. Kotikal, B. Tambat, and Ambika. D.S. 2020. Genetic Diversity of Appemidi Mango (Mangifera indica L.) in Belagavi district of Karnataka on Tree and Leaf Characters. Int.J.Curr.Microbiol.App.Sci. 9(02): 447451. doi: https://doi.org/10.20546/ijcmas.2020.902.55 